\title{
Broadleaf Weed Control in Sunflower (Helianthus annuus) with Preemergence-Applied Pyroxasulfone with and without Sulfentrazone
}

\author{
Seshadri S. Reddy, Phillip W. Stahlman, Patrick W. Geier \\ Agricultural Research Center, Kansas State University, Hays, KS, USA \\ Email: sajjala.reddy@gmail.com
}

Received 26 September 2015; accepted 10 November 2015; published 13 November 2015

Copyright (C) 2015 by authors and Scientific Research Publishing Inc.

This work is licensed under the Creative Commons Attribution International License (CC BY). http://creativecommons.org/licenses/by/4.0/

c) (i) Open Access

\begin{abstract}
A field study was conducted at two locations in Kansas, USA in 2011 and 2012 to test weed control efficacy and crop response to preemergence-applied pyroxasulfone alone and in combination with sulfentrazone in sunflower. Treatments included three rates of pyroxasulfone $(100,200$ and 400

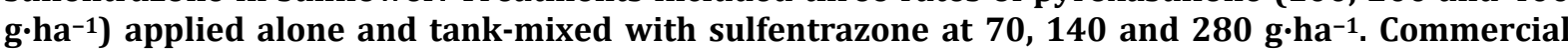
standards sulfentrazone at $140 \mathrm{~g} \cdot \mathrm{ha}^{-1}+$ pendimethalin at $1390 \mathrm{~g} \cdot \mathrm{ha}^{-1}$ and sulfentrazone at 140 $\mathrm{g} \cdot \mathrm{ha}^{-1}+S$-metolachlor at $1280 \mathrm{~g} \cdot \mathrm{ha}^{-1}$ were also included. Pyroxasulfone at $100 \mathrm{~g} \cdot \mathrm{ha}^{-1}$ controlled Palmer amaranth $87 \%$ at 3 weeks after application (WAA), but control decreased to $76 \%$ at 6 WAA. Increasing pyroxasulfone rate to $\geq 200 \mathrm{~g} \cdot \mathrm{ha}^{-1}$ or tank mixing with sulfentazone at $140 \mathrm{~g} \cdot \mathrm{ha}^{-1}$ pro- $^{-}$ vided $\geq 90 \%$ Palmer amaranth control for at least 6 WAA. Sulfentrazone alone at $70 \mathrm{~g} \cdot \mathrm{ha}^{-1}$ controlled Palmer amaranth $77 \%$ at 3 WAA, but control dropped to $69 \%$ at 6 WAA. Increasing sulfentrazone rate from 70 to 140 or $280 \mathrm{~g} \cdot$ ha $^{-1}$ increased control to $>90 \%$ at 3 WAA, but did not maintain acceptable control at 6 WAA. Tank mixing sulfentrazone at $140 \mathrm{~g} \cdot \mathrm{ha}^{-1}$ with pendimethalin at $1390 \mathrm{~g} \cdot \mathrm{ha}^{-1}$ or $S$-metolachlor at $1280 \mathrm{~g} \cdot \mathrm{ha}^{-1}$ controlled Palmer amaranth $\geq 90$ and $84 \%$ at 3 WAA and 6 WAA, respectively. The lowest rate of pyroxasulfone $\left(100 \mathrm{~g} \cdot \mathrm{ha}^{-1}\right)$ controlled kochia $98 \%$ and the control was complete with all other treatments. However, no treatment provided as much as $90 \%$ puncturevine control at 3 WAA and the control was commercially unacceptable $(<75 \%)$ at 6 WAA. No treatment visibly injured sunflower anytime during the season or reduced sunflower plant population.
\end{abstract}

\section{Keywords}

Pyroxasulfone, Sulfentrazone, Sunflower, Weed Control, Palmer Amaranth, Kochia 


\section{Introduction}

In the United States, sunflower (Helianthus annuus L.) is cultivated in the Great Plains Region for cooking oil, confectionary uses, and birdseed. In 2014, confection and oil-seed sunflower were planted on 0.63 million ha [1]. North Dakota (0.27 million ha), South Dakota (0.22 million ha) and Kansas (0.03 million ha) are the three major sunflower-growing states in the country. As with most field crops, sunflower is vulnerable to weed interference, especially during first 3 to 4 weeks after planting [2]. Maximum seed yields are reported when sunflower is kept weed free 4 to 6 weeks after planting [3]. Biennial wormwood (Artemisia biennis Willd.), Russian thistle (Salsola iberica Sennen \& Pau), Canada thistle (Cirsium arvense L. Scop.), green foxtail (Setaria viridis), kochia (Kochia scoparia L. Schrad.), redroot pigweed (Amaranthus retroflexus L.), wild buckwheat (Polygonum convolvulus L.), common lambsquarters (Chenopodium album L.) and common ragweed (Ambrosia artemisiifolia L.) are among the most common weeds interfering with sunflowers in the northern Great Plains (Minnesota, North Dakota, and South Dakota) [4]. The most common and troublesome weeds in sunflower fields in the central Great Plains (Colorado and Kansas) are Palmer amaranth (Amaranthus palmeri S. Watson), kochia, puncturevine (Tribulus terrestris L.) and Russian thistle [4].

Weeds can cause significant sunflower yield loss. Yield loss as much as $60 \%$ has been reported when a weed population consisting of large crabgrass Digitaria sanguinalis L. Scop.), goosegrass (Eleusine indica L. Gaertn.), sicklepod (Cassia obtusifolia L.), tall morningglory (Ipomea purpturea L. Roth), ivy leaf morningglory (I. hederacea L. Jacq.), and redroot pigweed competed with sunflowers for 8 weeks after planting [3]. Wild oat (Avena fatua L.) interference reduced sunflower yields by 54\% [5]. Season-long competition by kochia at densities of $0.3,1,3$, and 6 plants $\mathrm{m}^{-1}$ of row decreased sunflower seed yield by $7 \%, 10 \%, 20 \%$, and $27 \%$, respectively [6]. In a multi-location study in Northern Great Plains, when kochia plants emerged at the same time as the sunflowers, plant height, number of leaves, head diameter and stem diameter were reduced and as a result up to $76 \%$ yield losses were reported [7]. However, kochia plants that emerged after the four-leaf stage of the sunflower crop did not affect sunflower growth and development, yield, or seed quality [7]. Therefore, early weed management is necessary to prevent loss from weed interference in sunflower production. Most sunflower hectares receive a preemergence herbicide application but herbicide options for sunflower are limited, especially for control of many broadleaf weed species. Sulfentrazone, a protoporphyrinogen oxidase (PPO) inhibiting herbicide, is widely used for control of broadleaf weeds but it has little activity on grass weeds and is usually tank mixed with $S$-metolachlor or pendimethalin for broad spectrum weed control.

Pyroxasulfone (3-[[5-(difluoromethoxy)-1-methyl-3-(trifluoromethyl)pyrazol-4-yl]methylsulfonyl]-5,5-dimethyl$4 \mathrm{H}-1,2-0 x a z o l e)$ is a relatively new herbicide in the pyrazole herbicide family. It has preemergence activity and inhibits shoot elongation of susceptible seedling plants by inhibiting the biosynthesis of very-long-chain fatty acids [8]. Though pyroxasulfone is from a different herbicide family, it has the same mode of action as chloroacetamide herbicides (Group 15) including acetochlor, dimethenamid, and metolachlor. However, pyroxasulfone has higher specific activity than other Group 15 herbicides which allows for much lower use rates compared to chloroacetamide herbicides. Studies from western Kansas reported similar or greater weed control with pyroxasulfone at 125 to $500 \mathrm{~g} \cdot \mathrm{ha}^{-1}$ compared to $S$-metolachlor at 1070 to $4260 \mathrm{~g} \cdot \mathrm{ha}^{-1}$, which means effective use rates of pyroxasulfone were as low as approximately $12 \%$ of $S$-metolachlor use rates [9]. Fall application of pyroxasulfone at $209 \mathrm{~g} \cdot \mathrm{ha}^{-1}$ controled broadleaf signalgrass (Urochloa platyphylla (Nash.) R.D. Webster) and velvetleaf (Abutilon theophrasti Medik.) as much as 85 and 77\%, respectively at 197 days after treatment compared to 57 and $10 \%$, respectively with $S$-metolachlor at the same rate [10].

Pyroxasulfone is currently labeled in the United States for use in corn, soybean and wheat (Zidua ${ }^{\circledR}$, BASF Corporation, 26 Davis Dr, Research Triangle Park, NC 27709, USA). The maximum labeled use rate of pyroxasulfone for corn, soybean and wheat are 235, 206 and $118 \mathrm{~g} \cdot \mathrm{ha}^{-1}$, respectively. Several research reports have indicated effective annual grass and broadleaf weed control with pyroxasulfone. In non-irrigated corn in Kansas, pyroxasulfone at $250 \mathrm{~g} \cdot \mathrm{ha}^{-1}$ controlled green foxtail and Palmer amaranth 86 - 100\% and 87 - 99\%, respectively [9]. In furrow-irrigated corn in Montana, $\geq 94 \%$ control of velvetleaf and kochia, and $\geq 89 \%$ wild buckwheat control with $250 \mathrm{~g} \cdot \mathrm{ha}^{-1}$ of pyroxasulfone has been reported [11]. In a study in Louisiana, pyroxasulfone at 150 g.ha ${ }^{-1}$ controlled barnyardgrass (Echinochloa crus-galli L. Beauv), Palmer amaranth, and smooth pigweed (Amaranthus hybridus L.) 96 to $100 \%$ at 20 days after application [12]. Dose-response curves showed pyroxasulfone at 200 to $300 \mathrm{~g} \cdot \mathrm{ha}^{-1}$ provided excellent control of most grasses and certain broadleaf species in corn for at least 4 weeks of growing season on soils with up to 3\% organic matter [13]. 
Pyroxasulfone currently is not registered for use in sunflower. However, multiple coordinated field experiments from North Dakota to Kansas over a three-year period indicated preemergence (PRE)-applied pyroxasulfone controlled many annual grass and broadleaf weeds as well or better at rates three to eight-times lower than herbicides currently registered for use in sunflower with only occasional incidences of minor injury that did not reduce seed yield [14]. In two of those experiments, pyroxasulone at $208 \mathrm{~g} \cdot \mathrm{ha}^{-1}$ controlled Palmer amaranth 87 - 97\% and a tank mixture of $167 \mathrm{~g} \cdot \mathrm{ha}^{-1}$ pyroxasulfone plus $105 \mathrm{~g} \cdot \mathrm{ha}^{-1}$ sulfentrazone provided complete Palmer amaranth control [15]. The authors cautioned additional trials were needed to determine whether mixtures of pyroxasulfone and sulfentrazone consistently provide improved weed control compared to commercial herbicides. Hence, a study was conducted to evaluate weed control efficacy and sunflower response to different rates of pyroxasulfone with and without sulfentrazone.

\section{Material and Methods}

Field experiments were conducted during the 2011 and 2012 growing seasons near Hays (38.85N, 99.34W) and Colby (39.39N, 101.06W) in Kansas, USA. The Hays experimental site was rainfed and the Colby experimental site received supplemental irrigation periodically as needed to avoid moisture stress. Soil characteristics are shown in Table 1. Soil pH was measured in a 1:1 mixture of soil and water [16] and soil organic matter was measured by the Walkley-Black method [17]. The experimental design was a randomized complete block with four treatment replications. Experimental treatments included three rates of pyroxasulfone (100, 200 and 400 $\mathrm{g} \cdot \mathrm{ai} \cdot \mathrm{ha}^{-1}$ ) applied alone and tank-mixed with sulfentrazone at 70, 140 and $280 \mathrm{~g} \cdot \mathrm{ai} \cdot \mathrm{ha}{ }^{-1}$. Tank mixtures of pendimethalin at $1390 \mathrm{~g} \cdot \mathrm{ai} \cdot \mathrm{ha} \mathrm{a}^{-1}+$ sulfentrazone at $140 \mathrm{~g} \cdot \mathrm{ha}^{-1}, \mathrm{~S}$-metolachlor at $1280 \mathrm{~g} \cdot \mathrm{ai} \cdot \mathrm{ha} \mathrm{a}^{-1}+$ sulfentrazone at 140 $\mathrm{g} \cdot \mathrm{ha}^{-1}$ and a non-treated control were also included. Sunflower hybrids used and seeding rates are shown in Table 1. Sunflower hybrids were midseason, medium-height hybrids with favorable drydown characteristics. Seeds were planted in rows spaced $76 \mathrm{~cm}$ apart. Plots were 3 by $6.7 \mathrm{~m}$ with four rows of sunflower. Herbicides were applied PRE to crop and weeds using a $\mathrm{CO}_{2}$-powered backpack sprayer delivering $115 \mathrm{~L} \cdot \mathrm{ha}^{-1}$ at $220 \mathrm{kPa}$ pressure.

The predominate weed species was Palmer amaranth at both locations in 2011 and 2012. Kochia was present only at Colby in 2011 and puncturevine was present at both locations in 2012. Weed control was rated visually on a scale of 0 (no effect) to 100 (complete control). Weed control ratings were determined 3 and 6 weeks after treatment across sites and years. Crop response also was rated visually at 3 weeks after treatment on a scale of 0 to 100 . Unfortunately, seed yields were not determined because of late-season hail and/or substantial bird and wildlife damage (plants unrooted).

Data were analyzed using the general linear model procedure of the Statistical Analysis System (Statistical Analysis Systems Institute, Cary, NC, USA) and means were separated at the 5\% significance level using Fisher's protected LSD. Percent weed control data were arcsine transformed before analysis, but original values are

Table 1. Soil characteristics, planting and spraying information, 2011 and 2012.

\begin{tabular}{|c|c|c|c|c|}
\hline & \multicolumn{2}{|c|}{ Hays, KS } & \multicolumn{2}{|c|}{ Colby, KS } \\
\hline & 2011 & 2012 & 2011 & 2012 \\
\hline Geographic location & \multicolumn{2}{|c|}{ West-central Kansas } & \multicolumn{2}{|c|}{ Northwest Kansas } \\
\hline Soil type & Roxbury silt loam & Crete silty clay loam & Keith silt loam & Keith silt loam \\
\hline Soil pH & 7.8 & 6.1 & 7.2 & 7.2 \\
\hline Organic matter (\%) & 2.0 & 1.8 & 2.0 & 2.0 \\
\hline Sunflower hybrid & $\begin{array}{c}\text { Mycogen } \\
\text { 8N358CLDM }\end{array}$ & $\begin{array}{c}\text { Mycogen } \\
\text { 8N421CLDM }\end{array}$ & $\begin{array}{c}\text { Mycogen } \\
\text { 8N358CLDM }\end{array}$ & $\begin{array}{c}\text { Mycogen } \\
\text { 8N358CLDM }\end{array}$ \\
\hline Seed rate (Seeds $\cdot \mathrm{ha}^{-1}$ ) & 49,000 & 49,000 & 57,575 & 57,575 \\
\hline Planting date & 6/17/2011 & 6/11/2012 & 6/14/2011 & 6/06/2012 \\
\hline Herbicide application date & 6/20/2011 & 6/12/2012 & $6 / 15 / 2011$ & 6/06/2012 \\
\hline
\end{tabular}


presented in this paper. The control treatment was omitted from weed control analyses. Data were pooled over years and sites when there was no year-by-site-by-treatment interaction.

\section{Results}

Monthly mean temperature and total rainfall data at experimental sites during 2011 and 2012 are presented in Figure 1. Both years showed similar trends in air temperatures with highest in July and lowest in September and October. In 2011, a total of 276 and 360 mm rainfall was received during cropping season at Hays and Colby, respectively which was normal. However, in 2012, only around 50\% of the normal rainfall was received at both locations. In 2011, rainfall at Hays within the 3 days before PRE herbicide application totaled $34 \mathrm{~mm}$. The first beneficial rainfall was $25 \mathrm{~mm}$ at 17 days after herbicide application (DAA). At Colby, $46 \mathrm{~mm}$ rainfall was received over a period of 6 DAA. In 2012, 43 mm rainfall was received over a period of 4 DAA at Hays and 44 mm irrigation water was applied through overhead sprinkler system over a period of 5 DAA at Colby. Overall, the soil moisture received through rainfall or irrigation was sufficient to activate the PRE herbicides at both locations in 2011 and 2012.

\subsection{Palmer Amaranth Control}

Across sites and years, Palmer amaranth control with PRE-applied pyroxasulfone alone or in combination with sulfentrazone ranged from 87 to $99 \%$ at 3 weeks after application (WAA) and 76 to $98 \%$ at 6 WAA (Table 2). Pyroxasulfone alone at $100 \mathrm{~g} \cdot \mathrm{ha}^{-1}$ controlled Palmer amaranth $87 \%$ at 3 WAA. Increasing pyroxasulfone rate to 200 and $400 \mathrm{~g} \cdot \mathrm{ha}^{-1}$ increased Palmer amaranth control to 94 and 97\%, respectively. These results were similar to those of studies in Texas where at least 90\% Palmer amaranth control was achieved with $208 \mathrm{~g} \cdot \mathrm{ha}^{-1}$ of pyroxasulfone at 4 WAA [18]. In our study at 3 WAA, tank mixing pyroxasulfone at $100 \mathrm{~g} \cdot \mathrm{ha}^{-1}$ with sulfentrazone
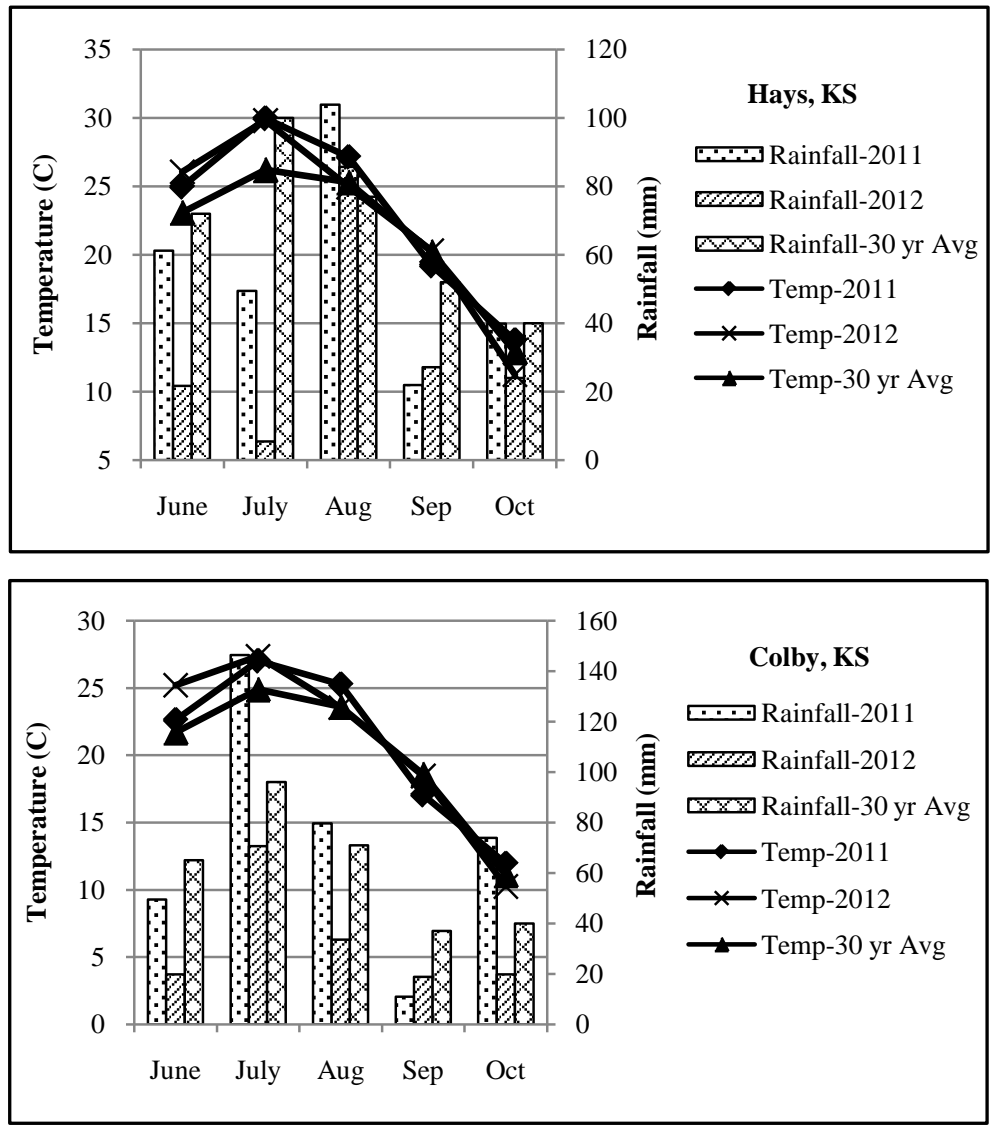

Figure 1. Weather data during cropping season 2011 and 2012. 
Table 2. Palmer amaranth and puncturevine control with pyroxasulfone and sulfentrazone combinations at 3 and 6 weeks after preemergence application ${ }^{\mathrm{a}, \mathrm{b}}$.

\begin{tabular}{|c|c|c|c|c|c|}
\hline \multirow{3}{*}{ Herbicide } & \multirow{3}{*}{ Rate } & \multicolumn{2}{|c|}{ Palmer amaranth } & \multicolumn{2}{|c|}{ Puncturevine } \\
\hline & & \multicolumn{2}{|c|}{ Pooled } & \multicolumn{2}{|c|}{ Colby, 2012} \\
\hline & & 3 WAA & 6 WAA & 3 WAA & 6 WAA \\
\hline & $g \cdot h a^{-1}$ & ---------------. & -----------. & -------. & --------- \\
\hline \multirow[t]{3}{*}{ Pyroxasulfone } & 100 & $87 \mathrm{c}$ & $76 \mathrm{gf}$ & 80 a & $64 \mathrm{ab}$ \\
\hline & 200 & $94 \mathrm{abc}$ & 91 abcd & $75 \mathrm{a}$ & $60 \mathrm{abc}$ \\
\hline & 400 & $97 \mathrm{ab}$ & $97 \mathrm{ab}$ & $70 \mathrm{abc}$ & 54 abcde \\
\hline \multirow[t]{3}{*}{ Sulfentrazone } & 70 & $77 \mathrm{~d}$ & $69 \mathrm{~g}$ & 45 de & 33 cdef \\
\hline & 140 & $92 \mathrm{abc}$ & $78 \mathrm{efg}$ & $40 \mathrm{e}$ & $15 \mathrm{f}$ \\
\hline & 280 & $93 \mathrm{abc}$ & 83 def & 68 abcd & 45 bcde \\
\hline \multirow[t]{9}{*}{ Pyroxasulfone + Sulfentrazone } & $100+70$ & $91 \mathrm{abc}$ & 86 bcdef & $73 \mathrm{ab}$ & 57 abcd \\
\hline & $100+140$ & $95 \mathrm{abc}$ & 93 abcd & $70 \mathrm{abc}$ & 50 abcde \\
\hline & $100+280$ & $97 \mathrm{ab}$ & 93 abcd & 67 abcd & 50 abcde \\
\hline & $200+70$ & $95 \mathrm{abc}$ & 89 abcde & 80 a & $59 \mathrm{abc}$ \\
\hline & $200+140$ & $97 \mathrm{ab}$ & 94 abcd & 86 a & $63 \mathrm{ab}$ \\
\hline & $200+280$ & $97 \mathrm{ab}$ & $95 \mathrm{abc}$ & $83 \mathrm{a}$ & $66 \mathrm{ab}$ \\
\hline & $400+70$ & $97 \mathrm{ab}$ & $97 \mathrm{ab}$ & 80 a & $64 \mathrm{ab}$ \\
\hline & $400+140$ & $97 \mathrm{ab}$ & $95 \mathrm{abc}$ & $88 \mathrm{a}$ & $74 \mathrm{a}$ \\
\hline & $400+280$ & 99 a & $98 \mathrm{a}$ & $85 \mathrm{a}$ & $70 \mathrm{ab}$ \\
\hline Sulfentrazone + Pendimethalin & $140+1390$ & $90 \mathrm{bc}$ & 84 cdef & 50 bcde & 28 ef \\
\hline Sulfentrazone $+S$-metolachlor & $140+1280$ & $91 \mathrm{abc}$ & 84 cdef & 48 cde & 30 ef \\
\hline
\end{tabular}

${ }^{\mathrm{a}}$ Data were arcsine transformed before analysis, but original values are presented in the table; ${ }^{\mathrm{b}}$ Means followed by the same letter do not differ significantly according to LSD at 5\%.

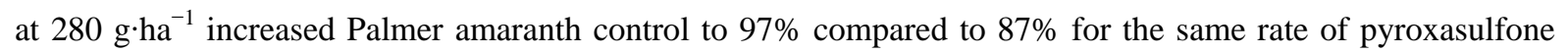
alone; however, it was similar to the same rate of sulfentrazone alone (93\%). Mixing higher rates of pyroxasulfone (200 and $400 \mathrm{~g} \cdot \mathrm{ha}^{-1}$ ) with any rate of sulfentrazone did not improve Palmer amaranth control. In a multi-location study conducted in Kansas, North Dakota and South Dakota, increased Palmer amaranth control by combining pyroxasulfone and sulfentrazone at the lowest rates tested $\left(167+105 \mathrm{~g} \cdot \mathrm{ha}^{-1}\right)$ compared to the same rate of pyroxasulfone alone was also reported previously [15].

At 3 WAA, sulfentrazone alone at $70 \mathrm{~g} \cdot \mathrm{ha}^{-1}$ provided the least Palmer amaranth control (77\%) of all the treatments tested (Table 2). Increasing sulfentrazone rate to $140 \mathrm{~g} \cdot \mathrm{ha}^{-1}$ increased Palmer amaranth control to $92 \%$. Further increasing sulfentrazone rate from 140 to $280 \mathrm{~g} \cdot \mathrm{ha}^{-1}$ or tank mixing sulfentrazone at $140 \mathrm{~g} \cdot \mathrm{ha}^{-1}$ with pendimethalin at $1390 \mathrm{~g} \cdot \mathrm{ha}^{-1}$ or $S$-metolachlor at $1280 \mathrm{~g} \cdot \mathrm{ha}^{-1}$ did not improve control compared to sulfentrazone alone at $140 \mathrm{~g} \cdot \mathrm{ha}^{-1}$. Sulfentrazone at $140 \mathrm{~g} \cdot \mathrm{ha}^{-1}$ was similarly effective as any rate of pyroxasulfone alone.

As the season progressed, Palmer amaranth control decreased in sunflower plots treated with lowest rate of pyroxasulfone (Table 2). The control with pyroxasulfone alone at $100 \mathrm{~g} \cdot \mathrm{ha}^{-1}$ decreased to $76 \%$ at 6 WAA compared to $87 \%$ at 3 WAA. However, tank mixing pyroxasulfone at $100 \mathrm{~g} \cdot \mathrm{ha}^{-1}$ with sulfentrazone at $140 \mathrm{~g} \cdot \mathrm{ha}^{-1}$ or more maintained Palmer amaranth control $>90 \%$ at 6 WAA. In a dose response study in a soil with $3 \%$ organic matter, it was reported that $152 \mathrm{~g} \cdot \mathrm{ha}^{-1}$ of pyroxasulfone was required for $90 \%$ control of tall waterhemp (Amaranthus tuberculatus (Moq.) at 4 WAA [13]. It was also reported that $198 \mathrm{~g} \cdot \mathrm{ha}^{-1}$ of pyroxasulfone was needed to 
achieve $90 \%$ control at 6 WAA. In our study, pyroxasulfone at 200 and $400 \mathrm{~g} \cdot \mathrm{ha}^{-1}$, with or without sulfentrazone, controlled Palmer amaranth $>90 \%$ at 6 WAA and there was little decline in control compared to 3 WAA. Conversely, Palmer amaranth control decreased to 69,78 and 83\% at 6 WAA compared to 77, 92 and $93 \%$ at 3 WAA in plots treated with sulfentrazone alone at 70, 140 and $280 \mathrm{~g} \cdot \mathrm{ha}^{-1}$, respectively. Tank mixing sulfentrazone at $140 \mathrm{~g} \cdot \mathrm{ha}^{-1}$ with pendimethalin at $1390 \mathrm{~g} \cdot \mathrm{ha}^{-1}$ or $S$-metolachlor at $1280 \mathrm{~g} \cdot \mathrm{ha}^{-1}$ did not improve Palmer amaranth control compared to sulfentrazone alone at 6 WAA. These results suggested that pyroxasulfone was more persistent and provided longer weed control compared to sulfentrazone. Pyroxasulfone has a relatively long soil half-life (35 to 45 days) [19].

\subsection{Puncturevine Control}

At Colby in 2012, no treatment provided $>88 \%$ puncturevine control at 3 WAA (Table 2). Pyroxasulfone at 100 $\mathrm{g} \cdot \mathrm{ha}^{-1}$ controlled puncturevine $80 \%$ at 3 WAA but control declined to $64 \%$ at 6 WAA. Increasing pyroxasulfone rate to $\geq 200 \mathrm{~g} \cdot \mathrm{ha}^{-1}$ or tank mixing with sulfentrazone did not increase puncturevine control. Sulfentrazone at 70 and $140 \mathrm{~g} \cdot \mathrm{ha}^{-1}$ provided much less puncturevine control (45 and 40\%, respectively) compared to pyroxasulfone at $100 \mathrm{~g} \cdot \mathrm{ha}^{-1}$. In an earlier study also in Kansas, poor puncturevine control (68\%) with sulfentrazone at 140 $\mathrm{g} \cdot \mathrm{ha}^{-1}$ was reported [20]. In the present study, increasing the rate of sulfentrazone from 140 to $280 \mathrm{~g} \cdot \mathrm{ha}^{-1}$ increased puncturevine control from 40 to $68 \%$. However, tank mixing sulfentrazone at $140 \mathrm{~g} \cdot \mathrm{ha}^{-1}$ with $\mathrm{S}$-me- tolachlor at $1280 \mathrm{~g} \cdot \mathrm{ha}^{-1}$ or pendimethalin at $1390 \mathrm{~g} \cdot \mathrm{ha}^{-1}$ did not increase control compared to the same rate of sulfentrazone alone.

At 6 WAA, puncturevine control decreased considerably with all treatments compared to 3 WAA. No treatment provided $\geq 75 \%$ control (Table 2). Even the highest rates of pyroxasulfone and sulfentrazone (400 and 280 $\mathrm{g} \cdot \mathrm{ha}^{-1}$, respectively) did not provide commercially acceptable puncturevine control (54 and 45\%, respectively). Greatest puncturevine control (74\%) at 6 WAA was achieved with pyroxasulfone at $400 \mathrm{~g} \cdot \mathrm{ha}^{-1}+$ sulfentrazone at $140 \mathrm{~g} \cdot \mathrm{ha}^{-1}$. However, in comparison, the commercial standards sulfentrazone at $140 \mathrm{~g} \cdot \mathrm{ha}^{-1}$ plus $S$-metolachlor at $1280 \mathrm{~g} \cdot \mathrm{ha}^{-1}$ or pendimethalin at $1390 \mathrm{~g} \cdot \mathrm{ha}^{-1}$ provided $\leq 30 \%$ control. At Hays, no significant difference in puncturevine control was observed among herbicide treatments (data not shown). Puncturevine control at Hays ranged from 83 to $96 \%$ at 3 WAA and 78 to $91 \%$ at 6 WAA. Heavy puncturevine seed bank in the soil at Colby could be the reason for lower performance of herbicide treatments against puncturevine at Colby compared to Hays.

\subsection{Kochia Control}

At Colby, PRE-applied pyroxasulfone at $100 \mathrm{~g} \cdot \mathrm{ha}^{-1}$ controlled kochia $98 \%$ and 200 and $400 \mathrm{~g} \cdot \mathrm{ha} \mathrm{a}^{-1}$ rates provided $100 \%$ control at 3 WAA (Table 3). Similarly, in a study in Montana, $95-100 \%$ control of kochia with

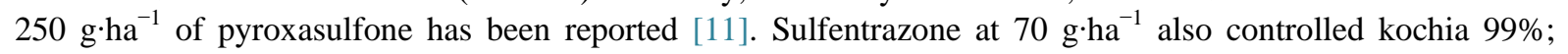

Table 3. Kochia control with pyroxasulfone and sulfentrazone combinations at 3 weeks after preemergence application, Colby, $2011^{\mathrm{a}, \mathrm{b}}$.

\begin{tabular}{|c|c|c|c|c|c|}
\hline & \multirow{3}{*}{$g \cdot h a^{-1}$} & \multicolumn{4}{|c|}{ Sulfentrazone } \\
\hline & & \multicolumn{4}{|c|}{ - } \\
\hline & & 0 & 70 & 140 & 280 \\
\hline & & ---------------' & 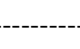 & ----- & ---------------- \\
\hline \multirow[t]{4}{*}{ Pyroxasulfone } & 0 & - & $99 \mathrm{~b}$ & $100 \mathrm{a}$ & 100 a \\
\hline & 100 & $98 \mathrm{~b}$ & 100 a & $100 \mathrm{a}$ & $100 \mathrm{a}$ \\
\hline & 200 & $100 \mathrm{a}$ & 100 a & $100 \mathrm{a}$ & 100 a \\
\hline & 400 & $100 \mathrm{a}$ & 100 a & $100 \mathrm{a}$ & $100 \mathrm{a}$ \\
\hline Pendimethalin & 1390 & - & - & $100 \mathrm{a}$ & - \\
\hline$S$-metolachlor & 1280 & - & - & $100 \mathrm{a}$ & - \\
\hline
\end{tabular}

${ }^{\mathrm{a}}$ Data were arcsine transformed before analysis, but original values are presented in the table; ${ }^{\mathrm{b}}$ Means followed by the same letter do not differ significantly according to LSD at 5\%. 
complete control at higher rates. Combinations of sulfentrazone at $140 \mathrm{~g} \cdot \mathrm{ha}^{-1}$ plus $S$-metolachlor at $1280 \mathrm{~g} \cdot \mathrm{ha}^{-1}$ or pendimethalin at $1390 \mathrm{~g} \cdot \mathrm{ha}^{-1}$ also provided complete control of kochia at 3 WAA. There was little or no change in kochia control for any treatment from 3 to 6 WAA (data not shown).

\subsection{Crop Injury}

No treatment visibly injured sunflower anytime during the season or reduced plant population in any site-year (data not shown). This is consistent with previous reports of excellent tolerance of sunflower to pyroxasulfone over a wide range of soils and environments [14] [15].

Results from this study support previous findings and indicate pyroxasulfone has potential to be a valuable preemergence herbicide in sunflower. Combinations of pyroxasulfone at $100 \mathrm{~g} \cdot \mathrm{ha}^{-1}$ and sulfentrazone at 140 $\mathrm{g} \cdot \mathrm{ha}^{-1}$ or pyroxasulfone alone at $200 \mathrm{~g} \cdot \mathrm{ha}^{-1}$ provided similar or greater broadleaf weed control with no crop in-

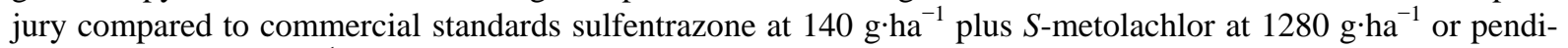
methalin at $1390 \mathrm{~g} \cdot \mathrm{ha}^{-1}$. Additional studies are needed on additional weed species over wide range of soils and environmental conditions.

\section{Acknowledgements}

The authors thank BASF Corporation for their financial support of this project. Contribution number 16-142-J from the Kansas Agricultural Experiment Station.

\section{References}

[1] USDA-NASS (United States Department of Agriculture National Agricultural Statistics Service) (2014) Data and Statistics/Quick Stats. USDA-NASS, Washington DC. www.quickstats.nass.usda.gov/

[2] Thompson, C.R., Peterson, D.E., Lyon, D.J., Olson, B.L.S., Kniss, A.R. and Falk, J.S. (2009) Weed Control. In: Meyer, R., Belshe, D., O’Brien, D. and Darling, R., Eds., High Plains Sunflower Production Handbook. MF-2384, Kansas State University Agricultural Experiment Station and Cooperative Extension Service, Manhattan, 8-10.

[3] Johnson, B.J. (1971) Effect of Weed Competition on Sunflower. Weed Science, 19, 378-380.

[4] Kandel, H. (2014) 2013 National Sunflower Association Survey. http://www.sunflowernsa.com/uploads/resources/683/2013.sunflower.survey_kandel_2014.pdf

[5] Chubb, W.O. and Friesen, G.H. (1985) Wild Oat Interference in Sunflower. Canadian Journal of Plant Science, 65, 219-222. http://dx.doi.org/10.4141/cjps85-031

[6] Durgan, B.R., Dexter, A.G. and Miller, S.D. (1990) Kochia (Kochia scoparia) Interference in Sunflower (Helianthus annuus). Weed Technology, 4, 52-56.

[7] Lewis, D.W. and Gulden, R.H. (2014) Effect of Kochia (Kochia scoparia) Interference on Sunflower (Helianthus annuus) Yield. Weed Science, 62, 158-165. http://dx.doi.org/10.1614/WS-D-13-00069.1

[8] Tanetani, Y., Kaku, K., Kawae, K., Fujioka, T. and Shimizu, T. (2009) Action Mechanism of a Novel Herbicide Pyroxasulfone. Pesticide Biochemistry and Physiology, 95, 47-55. http://dx.doi.org/10.1016/j.pestbp.2009.06.003

[9] Geier, P.W., Stahlman, P.W. and Frihauf, J.C. (2006) KIH-485 and S-Metolachlor Efficacy Comparisons in Conventional and No-Tillage Corn. Weed Technology, 20, 622-626. http://dx.doi.org/10.1614/WT-05-048R2.1

[10] Kurtz, M.E. (2011) Pyroxasulfone for Use in Southern States Soybean Production. Proceedings of Southern Weed Science Society, 64, 57.

[11] King, S.R. and Garcia, J.O. (2008) Annual Broadleaf Control with KIH-485 in Glyphosate-Resistant Furrow Irrigated Corn. Weed Technology, 22, 420-424. http://dx.doi.org/10.1614/WT-07-169.1

[12] Hardwick, J.M. (2013) Evaluation of Pyroxasulfone in Corn (Zea mays L.) and Soybean (Glycine max L. MERR.) Weed Management Programs. Thesis Submitted to Louisiana State University, Baton Rouge.

[13] Knezevic, S.Z., Datta, A., Scott, J. and Porpiglia, P.J. (2009) Dose-Response Curves of KIH-485 for Preemergence Weed Control in Corn. Weed Technology, 23, 34-39. http://dx.doi.org/10.1614/WT-08-097.1

[14] Stahlman, P.W., Olson, B.L.S., Thompson, C.R. and Zollinger, R.K. (2010) Pyroxasulfone (KIH-485) for Weed Control in Sunflower. Proceedings of the 1st Australian Summer Grains Conference, Gold Coast, 21-24 June 2010, 1-7.

[15] Olson, B.L., Zollinger, R.K., Thompson, C.R., Peterson, D.E., Jenks, B., Moechnig, M. and Stahlman, P.W. (2011) Pyroxasulfone with and without Sulfentrazone in Sunflower (Helianthus annuus). Weed Technology, 25, $217-221$. http://dx.doi.org/10.1614/WT-D-10-00089.1 
[16] Robertson, G.P., Sollins, P., Ellis, B.G. and Lajtha, K. (1999) Exchangeable Ions, pH, and Cation Exchange Capacity. In: Robertson, G.P., Coleman, D.C., Bledsoe, C.S. and Sollins, P., Eds., Standard Soil Methods for Long-Term Ecological Research, Oxford University Press, Oxford, 106-114.

[17] Combs, S.M. and Nathan, M.V. (1998) Soil Organic Matter. In: Brown, J.R., Ed., Recommended Chemical Soil Test Procedures for the North Central Region, North Central Regional Research Publication No. 221 (Revised), SB 1001, Missouri Agriculture Experiment Station, Columbia, 53-58.

[18] Gregory, L.S., Porpiglia, P.J. and Chandler, J.M. (2005) Efficacy of KIH-485 on Texas Panicum (Panicum texanum) and Selected Broadleaf Weeds in Corn. Weed Technology, 19, 866-869. http://dx.doi.org/10.1614/WT-04-229R1.1

[19] Anonymous (2006) KIH-485 Experimental Herbicide. Kumiai Chemical Industry Co., Ltd., White Plains, 8 p.

[20] Reddy, S.S., Stahlman, P.W., Geier, P.W. and Thompson, C.R. (2012) Weed Control and Crop Safety with Premixed S-Metolachlor and Sulfentrazone in Sunflower. American Journal of Plant Sciences, 11, 1625-1631. http://dx.doi.org/10.4236/ajps.2012.311197 